\title{
PERANCANGAN DAN IMPLEMENTASI SISTEM INFORMASI DESA WISATA KANDRI BERBASIS WEB
}

\author{
Suprihadi ${ }^{1}$ \\ Agustinus Fritz Wijaya $^{2}$ \\ Richard Gordon Mayopu ${ }^{3}$ \\ Staff Pengajar Fakultas Teknologi Informasi, Universitas Kristen Satya Wacana \\ e-mail : suprihadi@staff.uksw.edu,agustinus.wijaya@staff.uksw.edu,richard.mayopu@staff.uksw.edu
}

Diterima: 11 Mei 2016 / Disetujui: 23 Mei 2016

\begin{abstract}
Kandri is Gunungpati administrative area in the district, which is located in the city of Semarang in Central Java province which have Kreo Caves Nature Area. The tourist area has now been developed with the construction of dam Artificial Jatibarang which was completed in 2014. The reservoir has sunk acres of farmland, resulting in most of the Kandri citizens lose their livelihoods as farmers, and switch to the efforts in the field of tourism. Kandri rural communities in the development of a tourist village has set up a group called Pokdarwis tourism awareness in the form of a tourism cluster. The tourism cluster not yet have an information system that is capable of managing a data member, as well as a means of product promotion and online sales. This research aims to design a cluster of business information systems, and implement into web technology. System development method used is prototype models. The information system is implemented using the programming language PHP and CodeIgniter framework with a MySQL database. Results of this research is an e-commerce information system that features business profile information management, resource development and asset cluster members. These systems also use social plugins that like facebook as a marketing tool products. Thus, the information system can be used as an online store business clusters, media promotion, and data center can yield information about the development of the classification of business entities SME cluster members, so it can be used by cluster administrators and stakeholdesr in monitoring the business development of its members.
\end{abstract}

Keywords: Information System, Web, Appropriate Technology, E-Commerce, Cluster, Tourist Village.

\begin{abstract}
ABSTRAK
Kandri secara administratif merupakan wilayah Kecamatan Gunungpati, Kota Semarang Provinsi Jawa Tengah yang mempunyai Kawasan Wisata Alam Gua Kreo. Kawasan wisata tersebut saat ini telah dikembangkan dengan adanya pembangunan waduk buatan Jatibarang yang telah selesai pembangunannya pada Tahun 2014. Waduk tersebut telah menenggelamkan lahan pertanian warga, sehingga berakibat sebagian besar warga Kandri kehilangan mata pencahariannya sebagai petani, dan beralih pada usaha dalam bidang pariwisata. Masyarakat desa Kandri dalam upaya pengembangan desa wisata, telah membetuk sebuah kelompok sadar wisata (POKDARWIS) yang berbentuk sebuah klaster pariwisata. Klaster pariwisata tersebut belum memiliki sebuah sistem informasi yang mampu mengelola data anggota, sekaligus sebagai sarana promosi produk dan penjualan secara online. Penelitian ini bertujuan merancang sistem informasi klaster usaha, dan mengimplementasikan kedalam teknologi web. Metode pengembangan sistem yang digunakan adalah prototype model. Sistem informasi diimplementasikan menggunakan bahasa pemrograman PHP dan framework CodeIgniter, dengan basis data MySQL. Hasil penelitian ini adalah sebuah sistem informasi e-commerce yang memiliki fitur pengelolaan informasi profil usaha, pengembangan sumber daya dan aset anggota klaster. Sistem ini juga memanfaatkan social plugins yaitu like facebook sebagai alat pemasaran produk. Dengan demikian, sistem informasi ini dapat dipergunakan klaster usaha sebagai toko online, media promosi, dan pusat data yang dapat menghasilkan informasi perkembangan klasifikasi badan usaha UMKM anggota klaster, sehingga dapat dipergunakan oleh pengurus klaster dan stakeholders dalam memantau perkembangan usaha para anggotanya.
\end{abstract}




\section{PENDAHULUAN}

Kandri, merupakan sebuah kelurahan yang terletak di bawah kaki Gunung Ungaran, di sebelah selatan dari kota Semarang, secara geografis dilewati oleh sungai Kreo, dimana kegiatan sehari-hari warga kelurahan yang menggantungkan pencukupan ekonomi dari lahan persawahan selain dari kegiatankegiatan lainnya, antara lain sebagai buruh pabrik di wilayah kota Semarang. Kandri secara administratif merupakan wilayah Kecamatan Gunungpati, kota Semarang provinsi Jawa Tengah. Untuk lebih mengenal kelurahan Kandri, dapat dilihat pada gambar 1 mengenai data monografi kelurahan Kandri.

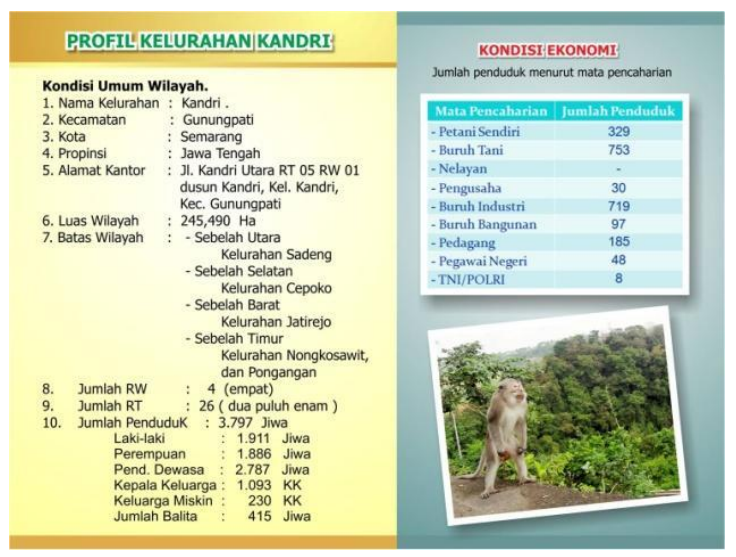

Gambar 1. Monografi Kelurahan Kandri

Kelurahan Kandri Kecamatan Gunungpati kota Semarang mempunyai kawasan wisata alam Gua Kreo, yang dikelola oleh Dinas Kebudayaan dan Pariwisata Kota Semarang. Sekarang, kawasan tersebut untuk sementara ditutup, karena adanya pembangunan Mega Proyek Waduk Jatibarang, yang direncanakan selesai pada Tahun 2014. Pembangunan waduk tersebut menenggelamkan lahan pertanian, yang berakibat sebagian warga Kandri kehilangan mata pencahariannya sebagai petani. Waduk, selain berfungsi sebagai penampung air, juga berfungsi sebagai obyek \& daya tarik wisata buatan. Hal ini berarti akan membuat harapan baru bagi warga Kandri, yaitu peluang usaha di bidang pariwisata dengan memberdayakan masyarakat untuk membentuk Desa Wisata.

Berbekal kenyataan tersebut diatas, dan dengan dukungan dari banyak pihak, elemen masyarakat, kelembagaan desa dan sumber daya manusia terdidik, maka kegiatan dalam rangka peningkatan kesejahteraan masyarakat mulai dikembangkan dan dirumuskan ke dalam kerangka desa wisata, yaitu meningkatkan kerukunan dan gotong-royong, semangat, serta kesadaran warga untuk menggali potensi alam, seni adat budaya, produk kriya, makanan dan minuman khas desa, untuk dilestarikan dan dijual kepada wisatawan yang akan berkunjung ke obyek wisata Waduk Jatibarang, maupun yang sengaja berwisata ke Desa Wisata Kandri sebagai tujuan utamanya. Adanya Curug Siwarak dan kondisi alamnya di kelurahan Kandri tidak hanya sebagai pendukung, tetapi juga dapat dikembangkan sebagai desa wisata destinasi atau tujuan obyek dan daya tarik wisata. Konsep strategi pengembangan Desa Wisata Kandri yaitu terciptanya pelayanan yang memuaskan, bernilai jual dan berdaya saing dengan daya tarik berupa produk alam, seni adat budaya, minat khusus, makananminuman khas desa dan berupaya memperhatikan keinginan, kebutuhan serta harapan wisatawan.

Kesadaran masyarakat didalam keterlibatan kerukunan dan gotong royong, dalam upaya peningkatan kesejahteraan dalam bidang usaha desa wisata telah, dilakukan sejak tahun 1993, yaitu adanya Kelompok Sadar Wisata (POKDARWIS) Pandanaran. Sejak tahun 1993, POKDARWIS Pandanaran telah melakukan kegiatan rutin tahunan dalam upaya pelestarian budaya lokal antara lain Sesaji Rewandha, Apitan dan Barian yang dilaksanakan di lokasi obyek wisata Goa Kreo di wilayah RW III kelurahan Kandri, serta acara ritual tahunan Nyadran Kali dan Nyadran Desa/Kubur yang telah cukup banyak menyerap wisatawan lokal maupun asing. Kelompok masyarakat lain yang bergerak dalam usaha yang sama dalam bidang pariwisata, seperti yang dilakukan oleh POKDARWIS Pandanaran yaitu POKDARWIS Suko Makmur. Kedua kelompok masyarakat tersebut berada dalam wilayah yang sama, yaitu di Desa Wisata Kandri.

Berdasarkan hal tersebut diatas yaitu adanya kegiatan aktif masyarakat yang bersifat 
partisipatif terhadap wisata alam dan budaya yang dimiliki Kandri, maka pada tahun 2012 pemerintah kota Semarang menerbitkan SK Walikota Semarang Nomor 556/407 tanggal 21 Desember 2012 tentang Penetapan Kelurahan Kandri Kecamatan Gunungpati sebagai Desa Wisata Kota Semarang berbasis Daya Tarik Alam dan Daya Tarik Budaya. Pada SK Walikota Semarang tersebut, Desa Wisata Kandri memiliki visi, yaitu Terwujudnya Desa Wisata yang Memuaskan Dalam Pelayanan, Bernilai Jual, Mbetahi dan Ngangeni. Sedangkan misi desa antara lain:

1. Mendukung program pemerintah dalam pembangunan kepariwisataan dengan menyediakan obyek wisata alternatif.

2. Menggali potensi desa untuk pembangunan masyarakat.

3. Memperluas lapangan kerja dan lapangan usaha bagi penduduk.

4. Menjaga dan Melestarikan Kearifan Budaya Lokal yang Tumbuh dan Berkembang di Masyarakat.

5. Menumbuhkan Rasa Cinta Dan Bangga Kepada Desa.

Berdasarkan kondisi tersebut, maka pada program penerapan dan pengembangan teknologi tepat guna telah dirancang dan diimplementasikan sebuah aplikasi sistem informasi Desa Wisata Kandri berbasis web. Sistem informasi sebagai hasil program penerapan dan pengembangan teknologi tepat guna, telah mampu dipergunakan sebagai sarana promosi dan dagang secara online, mengelola informasi terkait aset dan profil anggota klaster, sebagai pusat data pengumuman dan kegiatan klaster, dan dipergunakan sebagai sarana memantau perkembangan usaha kedalam bentuk klasifikasi usaha, serta mengelola sebagian data stratifikasi klaster. Dengan demikian, sistem informasi desa Wisata Kandri berbasis $w e b$, juga dapat dipergunakan sebagai sarana pendukung program destinasi pariwisata kota Semarang provinsi Jawa Tengah.

\section{PERMASALAHAN}

Permasalahan yang dihadapi saat ini oleh Klaster Pariwwisata Desa Wisata Kandri adalah sebagai berikut:

1. Belum memiliki pusat data atau basis data terkait kelompok usaha dan aset yang dimiliki klaster maupun anggota klaster.
2. Belum memiliki sistem informasi yang mampu menyimpan data, mengolah dan menyajikan informasi terkait Desa Wisata Kandri secara cepat dan tepat.

3. Minimnya kapasitas dan kompetensi sumber daya manusia dalam bidang teknologi informasi dan komunikasi.

4. Belum dapat mengemas produk dan paket wisata yang menarik dan kreatif.

5. Minimnya biaya promosi yang dimiliki anggota klaster atau kelompok usaha Desa Wisata Kandri.

6. Belum memiliki suatu alat berbasis teknologi informasi guna promosi dan pemasaran produk secara online yang terarah, terkoordinasi, dan berkelanjutan.

7. Belum tersedianya infrastruktur teknologi informasi dan komunikasi yang memadahi milik klaster.

Berdasarkan permasalahan yang tersebut, maka kegiatan penerapan dan pengembangan teknologi tepat guna di klaster Desa Wisata Kandri, yang berupa Perancangan dan Implementasi Sistem Informasi Desa Wisata Kandri Berbasis Web, memiliki tujuan agar POKDARWIS dapat antara lain:

1. Memiliki basis data yang dipergunakan sebagai pusat data dan informasi tentang usaha kelompok atau anggota klaster. Basis data klaster ini diharapkan mampu menyimpan dan menampung data-data usaha anggota klaster, yaitu pada saat ini terdapat 7 (tujuh) kelompok usaha. Datadata kelompok usaha anggota klaster, antara lain profil anggota, deskripsi atau katalog produk, dan persediaan produk.

2. Memiliki sistem informasi yang mampu menyediakan informasi terkait manajemen anggota klaster, antara lain informasi sumber daya anggota klaster, informasi kegiatan atau event, pusat informasi produk dan aset anggota (kelompok usaha), serta sebagai bahan pembelajaran terhadap masyarakat seputar kegiatan konservasi wisata alam dan budaya lokal Kandri.

3. Memiliki sistem informasi yang menyediakan fasilitas chatting sebagai alat komunikasi antar anggota klaster, klaster dengan masyarakat umum atau publik.

4. Memiliki web server dan domain yang dapat dipergunakan klaster sebagai pusat data dan aplikasi online yang dapat diakses oleh seluruh anggota klaster dan 
publik sebagai pusat informasi formal Desa Wisata Kandri.

Sedangkan manfaat yang dapat diperoleh dari kegiatan penerapan teknologi tepat guna ini adalah sebagai berikut:

1. Potensi Sosial dan Ekonomi.

Aplikasi yang dibangun sebagai sarana promosi berbasis teknologi informasi, sehingga dapat dipergunakan sebagai media pemasaran online produk klaster Desa Wisata Kandri. Hal ini dapat mengurangi pengeluaran biaya promosi dan pemasaran yang selama ini dilakukan melalui media pameran dan bazar.

2. Nilai Tambah dari Sisi IPTEKS.

Dampak fungsional hasil perancangan dan implementasi sistem informasi Desa Wisata Kandri adalah terwujudnya pusat data dan informasi Desa Wisata Kandri. Sistem informasi juga dapat dipergunakan sebagai sarana pertanggungjawaban dan transparansi publik pihak klaster terhadap masyarakat dan pemangku kepentingan, yang selama ini mendukung dan memfasilitasi demi kemajuan Desa Wisata Kandri. Bagi pengurus klaster, sistem informasi dapat memicu peningkatan kemampuan IPTEKS, khususnya dalam bidang Teknologi Informasi dan Komunikasi.

3. Dampak Ikutan.

Untuk dapat mewujudkan keberlangsungan operasional sistem informasi Desa Wisata Kandri, maka klaster melibatkan pihak karang taruna kelurahan Kandri untuk berpartisipasi dalam operasional dan maintenace sistem informasi. Oleh karena itu, pihak klaster dalam pelaksanaannya akan membentuk KIM (Kelompok Informasi Masyarakat) Desa Wisata Kandri.

4. Nilai Tambah Bagi Perguruan Tinggi dan Pemerintah.

Manfaat bagi Perguruan Tinggi adalah sebagai sarana kegiatan penelitian dan pengabdian kepada masyarakat bagi dosen dan mahasiswa, khususnya didalam kegiatan penerapan teknologi informasi dan komunikasi pada klaster pariwisata. Manfaat yang dapat diperoleh bagi pemerintah setempat dan pemerinta kota Semarang khususnya Dinas Kebudayaan dan Pariwisata, Bappeda Kota dan Provinsi adalah tersedianya informasi terkait klaster binaan dalam bidang pariwisata secara cepat dan akurat.

Dari penjelasan di atas, dapat dirumuskan beberapa permasalahan yaitu sebagai berikut :

1. Bagaimana merancang dan mengimplementasikan suatu aplikasi yang dapat dipergunakan sebagai pusat data atau basis data yang mampu menyimpan, mengolah dan menyajikan informasi terkait data profil, kegiatan, aset klaster, dan transaksi penjualan produk anggota klaster secara cepat, tepat dan bersifat online?

2. Bagaimana merancang dan mengimplementasikan aplikasi tersebut supaya dapat dipergunakan sebagai alat promosi dan pemasaran produk secara online, sehingga dapat membantu mengatasi minimnya biaya promosi kelompok klaster, serta sekaligus dapat dipergunakan sebagai sarana komunikasi antar anggota klaster?

\section{LITERATURE REVIEW}

Berbagai penelitian yang terkait dengan topik perancangan dan implementasi sistem informasi desa wisata berbasis web telah banyak dilakukan. Beberapa diantaranya antara lain yaitu:

1. Penelitian yang terkait dengan $e$ commerce, yaitu yang dilakukan oleh Hidayat, dkk., pada tahun 2010 dengan judul: "Perancangan dan Implementasi Sistem E-Commerce dengan Menggunakan CMS OpenCart dalam Upaya Meningkatkan Penjualan dan Pemasaran (Studi Kasus: UD. La Tanza Kecamatan Dau Malang)". Dalam penelitian tersebut dibahas mengenai UD. La Tanza yang merupakan salah satu usaha kecil dan menengah (UKM) unggulan di kota Malang, Jawa Timur yang memproduksi berbagai makanan organik. UD. La Tanza memiliki permasalahan dalam hal peningkatan penjualan melalui promosi atau pemasaran produk yang kurang efektif, sehingga UD. La Tanza mengalami kesulitan dalam memperkenalkan produk-produk makanan organiknya kepada konsumen. Sistem penjualan offline 
yang diterapkan oleh UD. La Tanza belum mampu menjangkau pasar secara luas, hanya terbatas pada daerah sekitar UD. LA Tanza. Untuk mengatasi permasalahan tersebut, maka dibangun sistem penjualan online berbasis web (e-commerce) untuk memberikan informasi yang lengkap mengenai produk-produk UD. La Tanza kepada konsumen sehingga mempermudah UD. La Tanza dalam meningkatkan penjualan dan pemasaran produk-produknya [1].

2. Penelitian yang terkait dengan sistem informasi klater yaitu yang dilakukan oleh Setyawan pada tahun 2013, dengan judul: "Perancangan Aplikasi Web E-Business untuk Klaster Industri Alas Kaki di Jawa Timur". Pada penelitian tersebut dijelaskan bahwa Klaster Industri Alas Kaki (KIAK) di Jawa Timur dipilih karena merupakan salah satu klaster industri yang sedang diprioritaskan pengembangannya oleh Dinas Perindustrian dan Perdagangan Jawa Timur, dan dijadikan pilot project untuk pengembangan klaster lainnya di masa mendatang. Beberapa permasalahan utama yang dihadapi KIAK ialah (1) bagaimana meningkatkan keterkaitan antar anggota klaster sehingga menciptakan sinergi dalam aktivitas bernilai tambah mereka, dan (2) bagaimana melakukan pemasaran ke pasar ekspor agar produk alas kaki tersebut bisa dikenal dan bersaing. Penelitian ini, pertama bertujuan untuk mengidentifikasi dan memetakan keterkaitan (linkage), rantai nilai, dan aliran sharing informasi antar stakeholder klaster yang selanjutnya dirancang menjadi $e$ business. Tujuan kedua ialah merancang mekanisme pemasaran lewat internet yang akan diwujudkan dalam pengembangan online trading (web e-commerce), untuk mendukung pemasaran nasional dan global. Penelitian ini menggunakan metode action research, karena diperlukan keikutsertaan stakeholder klaster dan adanya tindakan yang diharapkan pada mereka. Prinsip-prinsip dalam metodologi pengembangan sistem informasi dan metode prototyping digunakan dalam proses perancangan sistem e-business. Hasil penelitian ini diharapkan akan bermanfaat dalam (1) memberikan kontribusi ilmiah tentang penerapan e-business di klaster industri di negara berkembang, (2) menjadi kerangka pertimbangan bagi pembuat kebijakan, dan (3) menghasilkan prototype web $e$ business yang siap untuk dioperasikan [2].

3. Penelitian yang terkait dengan desa wisata yaitu yang dilakukan oleh Aprillia, dkk., pada tahun 2013 dengan judul: "Aplikasi Web pada Desa Wisata Sambi Yogyakarta Sebagai Media Promosi”. Dalam penelitian tersebut dibahas mengenai website, atau yang lebih dikenal sebagai internet adalah salah satu media presentasi informasi yang sangat populer di era sekarang ini dengan segala kelebihan, yang memungkinkan informasi yang akan didistribusikan dengan cepat, akurat dan dapat diakses secara global. Sehingga, distribusi informasi dengan sistem ini cenderung kurang efektif daripada melalui media cetak atau media elektronik lainnya. Tujuan dalam penelitian tersebut adalah untuk mendirikan sebuah layanan informasi pada Desa Wisata Alam Sambi Yogyakarta, dengan menggunakan aplikasi web, melalui teknologi internet sebagai media yang akan membantu memfasilitasi penyampaian informasi kepada publik. Website yang dibangun terlihat menarik, sehingga mudah diterima oleh setiap pengunjung dan menambah daya tarik bagi Desa Wisata Alam Sambi Yogyakarta. Dengan adanya aplikasi web Desa Wisata Alam Sambi Yogyakarta, maka akan memberikan dan menyajikan informasi kepada publik yang secara online melalui internet yang dapat diakses di mana saja, kapan saja, tanpa batas ruang, waktu dan jarak. Sistem ini akan menyajikan informasi secara akurat, tepat waktu dan relevan, dan untuk meningkatkan pelayanan informasi kepada masyarakat luas, yang juga 
mengurangi biaya promosi yang berlebihan [3].

\section{PEMECAHAN MASALAH}

Untuk dapat merealisasikan penyelesaian masalah, maka program penerapan dan pengembangan teknologi tepat guna bagi kelompok sasaran telah dilaksanakan sebuah pengembangan system, berupa aplikasi web sistem jejaring usaha bagi UMKM berbasis klaster, dimana telah di-hosting dengan domain iklaster.com. Pengembangan aplikasi web tersebut sebagai teknologi tepat guna adalah sebagai berikut:

1. Adanya fasilitas galeri video.

Untuk dapat menyajikan informasi yang lebih representatif, maka disediakan fasilitas galeri video bagi klaster pada aplikasi. Hal ini direalisasikan karena produk klaster saat ini lebih bervariatif, yaitu dapat berupa produk barang dan produk jasa. Dengan demikian, informasi dapat disajikan kedalam format teks, gambar dan video, sehingga publik maupun relasi yang dimiliki kelompok sasaran mendapatkan informasi yang lebih variatif dan menarik.

2. Adanya fasilitas stratifikasi klaster. Stratifikasi klaster adalah pengelompokan tahapan pertumbuhan klaster, yaitu Klaster Pemula, Klaster Berkembang dan Klaster Maju. Stratifikasi klaster dipergunakan untuk kepentingan pembinaan agar tepat sasaran sesuai dengan tingkat kemajuan masing-masing klaster[4]. Berdasarkan acuan tersebut, maka aplikasi telah dikembangkan guna kelola data stratifikasi klaster yang dapat diakses oleh pengurus dan anggota klaster. Pada tahap ini, stratifikasi klaster yang dapat diakses adalah pengembangan yang telah dilaksanakan anggota klaster, pengembangan yang telah diusulkan anggota klaster, potensi klaster, input aset anggota klaster, dan laporan klasifikasi klaster berdasarkan total penjualan dan aset anggota.

3. Adanya fasilitas kelola transaksi penjualan produk anggota klaster. Fasilitas ini diberikan bagi anggota klaster untuk mendapatkan informasi transaksi penjualan produk yang dimilikinya, baik transaksi penjualan secara online pada aplikasi, maupun penjualan tidak secara online atau
COD (cash on delivery). Data transaksi penjualan ini sangat penting bagi klaster, karena dipergunakan sebagai salah satu parameter stratifikasi klaster untuk klasifikasi usaha klaster.

4. Adanya fasilitas pemantauan klasifikasi usaha klaster. Fasilitas pemantauan klasifikasi usaha klaster merupakan laporan stratifikasi klaster, dimana pada tahap ini masih berdasarkan pengolahan data total aset anggota klaster dan total penjualan produk anggota klaster. Klasifikasi usaha klaster terbagi kedalam kelompok usaha mikro, kecil dan menengah.

5. Adanya fasilitas pemantauan promosi produk. Fasilitas pemantauan promosi produk dipergunakan oleh anggota klaster untuk mengetahui tingkat keberhasilan promosi melalui aplikasi sistem jejaring usaha UMKM berbasis klaster iklaster.com. Data diperoleh dengan cara aplikasi mencatat jumlah Share dan like pada produk anggota klaster, oleh pihak lain melalui media sosial yaitu facebook, serta jumlah hit halaman produk.

Untuk dapat menerapkan aplikasi web sebagai teknologi tepat guna bagi kelompok sasaran, maka telah dilaksanakan pelatihan dan pendampingan pengunaan aplikasi secara berkala dan berkelanjutan selama program penelitian ini, sehingga dapat meningkatkan kapasitas dan kompetenesi dalam bidang teknologi informasi dan komunikasi. Pada program ini, juga telah dilaksanakan workshop kehumasan dasar guna peningkatan kemampuan klaster dalam mengemas informasi klaster, produk anggota dan paket wisata secara menarik, tepat dan kreatif melalui aplikasi web teknologi tepat guna yang dibangun.

Metode yang digunakan dalam penelitian penerapan dan pengembangan teknologi tepat guna bagi klaster Desa Wisata Kandri secara pokok adalah sebagai berikut:

1. Perancangan sistem informasi manajemen klaster Desa Wisata Kandri.

2. Pengembangan teknologi tepat guna berupa perangkat lunak aplikasi web sistem informasi Desa Wisata Kandri.

3. Pendampingan dalam penerapan dan perawatan aplikasi sistem informasi Desa Wisata Kandri berbasis web sebagai hasil program teknologi tepat guna. 
Untuk lebih dapat lebih jelas langkah pelaksanaan program, dapat dilihat pada gambar 2.

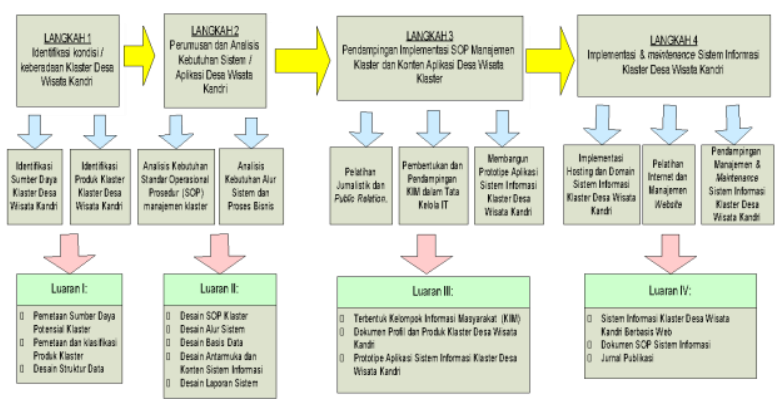

Gambar 2. Metode Penerapan dan

Pengembangan Teknologi Tepat Guna Bagi Klaster Desa Wisata Kandri

Keterangan gambar 2 adalah sebagai berikut: Langkah 1:

Identifikasi kondisi / keberadaan klaster Desa Wisata Kandri. Tahap ini merupakan kegiatan survei dan observasi untuk mendapatkan informasi dan data-data yang tepat antara lain:

1) Sumber daya manusia.

- Potensi pada bidang teknologi informasi dan komunikasi.

- Manajerial dan kepemimpinan.

2) Infrastruktur manajemen dan kelembagaan.

$$
\begin{aligned}
& \text { - } \quad \text { AD/ART Kelembagaan. } \\
& \text { - } \quad \text { Badan hukum kelembagaan. } \\
& \text { - } \quad \text { Struktur organisasi \& job } \\
& \text { description. } \\
& \text { - } \quad \text { Manajemen keuangan. }
\end{aligned}
$$

3) Sarana dan prasarana.

- Inventarisasi kelembagaan dan kelompok klaster.

- Pendataan alat produksi dan kemasan.

4) Produk kelompok usaha angota klaster.

- Pendataan jumlah dan jenis produk yang layak dan siap dijual. jelas.

Pada tahap ini, klaster Desa Wisata Kandri harus berperan aktif dalam memberikan informasi dan data-data yang tepat kepada tim pelaksana program. Alat bantu identifikasi pada tahap ini berupa kuosioner dan form-form isian pendataan. Hasil pada langkah 1 adalah pemetaan sumber daya potensial klaster, pemetaan dan klasifikasi produk klaster dan desain struktur data.
Langkah 2:

Perumusan dan analisis kebutuhan sistem / aplikasi Desa Wisata Kandri. Pada langkah ke-2 ini mengajak masyarakat sasaran untuk merancang Standard Operating Procedure (SOP) dalam mengelola kelembagaan klaster yang berupa klaster pariwisata berdasarkan potensi dari hasil langkah ke-1, antara lain:

1) Prosedur untuk mengelola anggota klaster, baik ukm maupun kelompok usaha.

2) Prosedur untuk menyimpan, update dan menampilkan produk kelompok usaha.

3) Prosedur untuk menyimpan, update dan menampilkan profil anggota.

4) Prosedur layanan pengaduan dan mekanisme penjaminan mutu kegiatan kepariwisataan Desa Wisata Kandri.

5) Prosedur layanan dan etika dalam komunikasi antar anggota klaster, klaster dengan publik atau sebaliknya didalam sistem informasi.

6) Perancangan proses bisnis sebagai dasar laporan analisis bisnis klaster Desa Wisata.

7) Penentuan aktor dan hak akses pengguna.

Berdasarkan kesepakatan rancangan SOP tersebut, maka dilakukan desain alur sistem dan bisnis proses sebagai dasar membangun aplikasi Sistem Informasi Desa Wisata Kandri berbasis web. Hasil pada langkah 2 adalah desain SOP klaster, desain alur sistem, desain basis data, desain antarmuka dan konten sistem informasi, dan desain laporan sistem.

\section{Langkah 3:}

Pendampingan implementasi SOP manajemen klaster dan konten aplikasi Desa Wisata Kandri. Pada tahap ini dilakukan uji SOP dengan cara simulasi. Pada rentang waktu yang sama juga dilakukan pelatihan kepada pengurus, anggota klaster dan perwakilan Karang Taruna kelurahan Kandri, yaitu pelatihan Jurnalistik dan Public Relation.

Pelatihan ini bertujuan agar klaster mampu menampilkan dan mendeskripsikan produk dan kegiatan kepariwisataan klaster sebagai konten di Sistem Informasi Desa Wisata Kandri, dengan tata bahasa yang benar, santun dan mudah dipahami publik, serta mampu mencitrakan Desa Wisata Kandri ke dunia Internasional. Dengan demikian, diharapkan sistem informasi yang bersifat online milik Desa Wisata Kandri, dapat 
mencerminkan budaya dan kearifan local, serta mengangkat citra kota Semarang.

Setelah diberikan pelatihan maka dilakukan pembentukan Kelompok Informasi Masyarakat (KIM) untuk mempersiapkan langkah selanjutnya. KIM memiliki kepengurusan dan keanggotaan dari perwakilan pemuda Karang Taruna kelurahan Kandri. KIM diharapkan mampu bertugas sebagai partner klaster Desa Wisata Kandri didalam mengelola Sistem Informasi Desa Wisata Kandri berbasis web, secara berkesinambungan dan kontinu.

Pada waktu yang bersamaan, proses implementasi aplikasi sistem informasi berdasarkan alur sistem dan basis data langkah 2 juga dilaksanakan. Pada langkah 3, aplikasi selalu diuji coba dan dievaluasi berdasarkan perkembangan SOP pada saat simulasi langkah 3 yang dilakukan oleh masyarakat sasaran yaitu klaster. Dengan demikian, tahap ini dapat menghasilkan SOP dan prototipe akhir Sistem Informasi Desa Wisata Kandri, yang merupakan penyempurnaan rancangan SOP, alur sistem dan kebutuhan basis data dari langkah 2.

\section{Langkah 4:}

Implementasi \& maintenance Sistem Informasi Desa Wisata Kandri. Pada tahap ini domain dan hosting web server sistem informasi desa wisata harus sudah tersedia. Kemudian, klaster melalui KIM memulai proses pengisian konten dan menjalankan sistem informasi dengan didampingi oleh tim pelaksana program, untuk beberapa waktu guna menjaga terjadinya maintenance/perubahan struktur dan terjadinya kesalahan pada aplikasi. Pada tahap ini juga, klaster bersama KIM sebagai pengelola mendapatkan pelatihan sebagai Admin domain dan hosting web server. Sistem Informasi Desa Wisata Kandri merupakan aplikasi berbasis web, dimana aplikasi dan basis data berada pada lokasi web server. Oleh karena itu, dibutuhkan pelatihan guna mendapatkan ketrampilan dan pengetahuan tentang pengelolaan domain dan hosting web server bagi klaster. Peserta pelatihan ini sebaiknya lebih dari 1 (satu) orang dari klaster khususnya yang memiliki pengalaman pendidikan dalam bidang teknologi informasi, yang nantinya akan bertugas sebagai admin sistem informasi.

Desain aplikasi Sistem Informasi Desa Wisata Kandri, merupakan pengembangan dari teknologi tepat guna yang sudah berjalan yaitu Sistem Jejaring Bisnis UMKM dan Koperasi berbasis Klaster, dengan domain iklaster.com. Aplikasi web iklaster.com pada prinsipnya merupakan aplikasi e-commerce kategori b2c (business-to-consumer) yang disediakan bagi klaster dan para anggotanya, dimana aplikasi tersebut belum memiliki fasilitas layanan pengolahan informasi, yaitu informasi terkait kelembagaan usaha anggota (badan usaha, jenis usaha dan pemberdayaan), informasi pemasaran produk berbasis teknologi informasi dan informasi, transaksi penjualan produk, sehingga dapat dirangkum didalam sebuah sistem informasi klaster. Pengembangan sistem informasi klaster dalam penelitian ini mengambil sampel data dan kasus di Desa Wisata Kandri, kelurahan Kandri kecamatan Gunungpati, kota Semarang, provinsi Jawa Tengah.

Desain pengembangan Sistem Informasi Klaster tersebut direpresentasikan menggunakan metode Unified Modelling Language (UML), dalam bentuk use case diagram yang dapat dilihat pada gambar 3 . Use case diagram mampu memperlihatkan hubungan antara aktor (pengguna) sistem dengan proses-proses yang dimiliki oleh Sistem Informasi Klaster tersebut, sehingga use case diagram dapat dipergunakan sebagai deskripsi teknis, operasional dan kemanfaatan dari sistem informasi yang merupakan aplikasi teknologi tepat guna. Pada gambar 3, terlihat bahwa Sistem Informasi Klaster terdapat 4 (empat) aktor, yaitu Guest, Admin Klaster, Anggota Klaster dan Admin Portal.

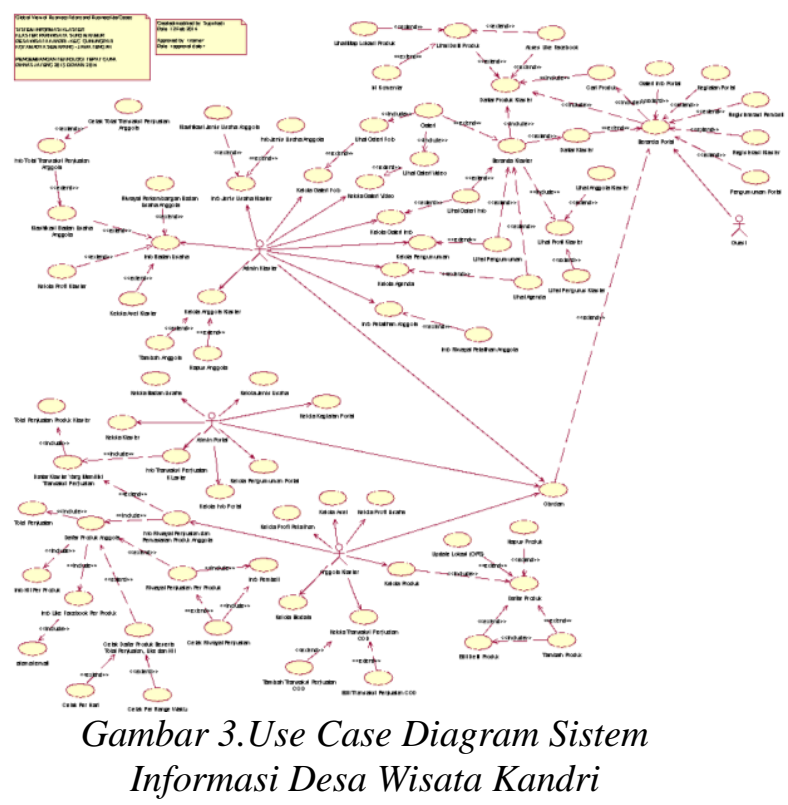


Aktor Guest merupakan aktor yang berperan sebagai tamu di dalam sistem yaitu para masyarakat luas (dunia) yang ingin melakukan transaksi dengan klaster dan dalam hal ini aktor Guest yaitu orang yang dapat berinteraksi dengan sistem melalui fitur-fitur Beranda Portal yang terdapat di dalam Sistem Informasi Klaster seperti pada gambar 4. Berdasarkan gambar 4 tersebut, aktor Guest dapat melakukan interaksi dengan sistem informasi klaster melalui Beranda Portal, dalam menu Beranda Portal tersebut, aktor Guest dapat melakukan Pencarian Produk, melihat Galeri Info Portal, melihat Kegiatan Portal, melakukan Registrasi Pembeli, melakukan Registrasi Klaster, dan melihat Pengumuman Portal. Pada Beranda Portal ini juga, aktor Guest dapat melihat Daftar Klaster, dimana menu ini akan menghubungkan dengan menu Beranda Klaster yang berisi Lihat Galeri Info, melihat Pengumuman Klaster, melihat Agenda Klaster, melihat Profil Klaster yang terdiri dari Anggota dan Pengurus Klaster. Kelebihan Sistem Informasi Desa Wisata Kandri ini yaitu aktor Guest dapat berkontribusi dalam melakukan promosi bagi klaster maupun produk yang ada di dalam sistem informasi ini. Hal ini dapat dilihat pada menu Pencarian Produk, maka aktor Guest dapat melihat Daftar Produk Klaster dan dapat memberikan penilaian atau mengisi komentar, atau bahkan dengan cara memanfaatkan media sosial yaitu Like Facebook terhadap produk yang sedang dilihat tersebut. Pengembangan teknologi ini juga memberi kemudahan bagi publik atau aktor Guest, yaitu dapat mengetahui lokasi usaha atau produk dari Anggota Klaster melalui fasilitas GoogleMap, sehingga dapat dipergunakan untuk sarana penunjuk arah perjalanan bagi publik atau aktor Guest terutama jika berada dalam kota yang sama dengan pemilik produk.

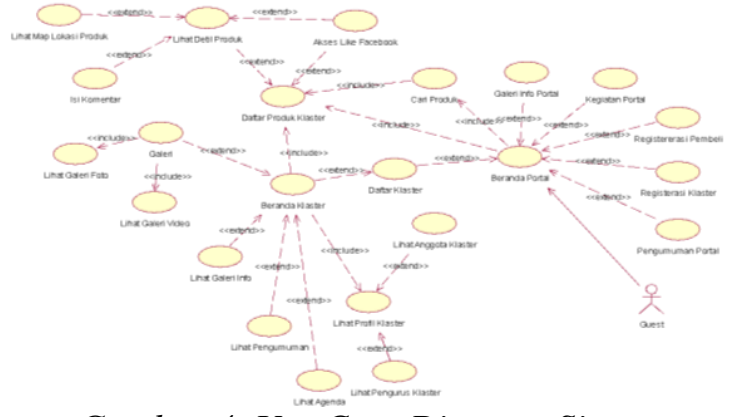

Gambar 4. Use Case Diagram Sistem

Informasi Desa Wisata Kandri Aktor Guest
Aktor Admin Klaster merupakan aktor yang berperan sebagai pengelola klaster di Desa Wisata Kandri. Aktor Admin Klaster dapat berinteraksi dengan sistem melalui beberapa menu yang terdapat di dalam sistem informasi klaster, seperti pada gambar 5 . Gambar 5 menjelaskan bagaimana hubungan interaksi antara aktor Admin Klaster dengan sistem, dimana aktor Admin Klaster dapat melakukan pengelolaan Anggota Klaster, pengelolaan Badan Usaha, pengelolaan Jenis Usaha Klaster, mengelola Galeri Foto, mengelola Galeri Video, mengelola Galeri Info, mengelola Pengumuman, mengelola Agenda, dan mengelola Info Pelatihan Anggota. Melalui Info Badan Usaha, maka aktor Admin Klaster dapat melakukan pengelolaan badan usaha setiap anggota apakah anggota tersebut masuk kedalam kategori badan usaha mikro, kecil, atau menengah berdasarkan besarnya transaksi penjualan setiap anggota klaster per tahunnya. Melalui menu tersebut, aktor Admin Klaster dapat melihat Riwayat Perkembangan Badan Usaha Anggota, sehingga dapat memberikan pembinaan kepada anggota yang masih belum meningkat usahanya. Dalam sistem informasi klaster ini, aktor Admin Klaster juga dapat melakukan klasifikasi dan informasi Jenis Usaha Anggota melalui menu Info Jenis Usaha anggota.

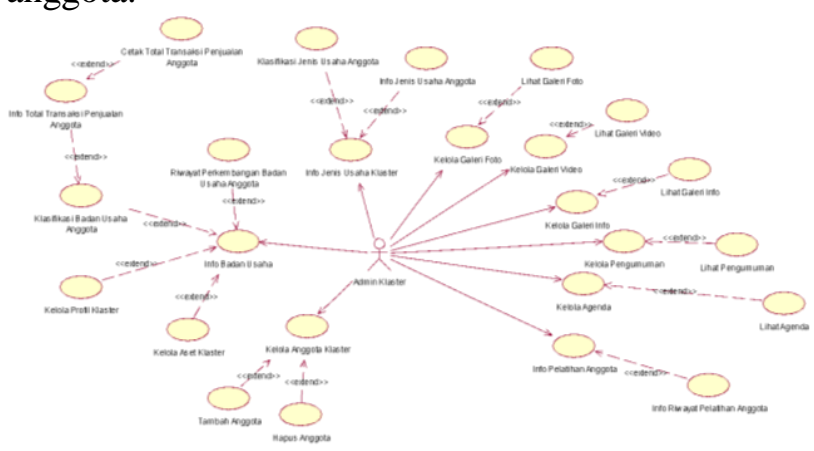

Gambar 5.Use Case Diagram Sistem Informasi Desa Wisata Kandri Aktor Admin Klaster

Aktor Anggota Klaster merupakan orang yang mempunyai usaha dalam klaster di Desa Wisata Kandri. Fungsi-fungsi yang dapat dilakukan oleh anggota klaster di dalam sistem informasi klaster ini seperti pada gambar 6 . 


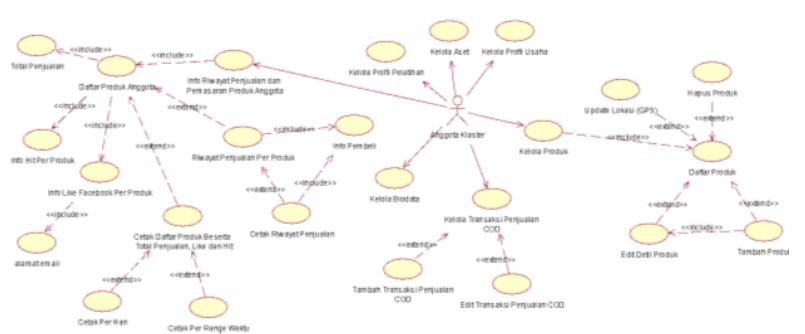

Gambar 6.Use Case Diagram Sistem Informasi Desa Wisata Kandri Aktor Anggota Klaster

Berdasarkan gambar 6, aktor Anggota Klaster dapat melakukan beberapa fungsi di dalam sistem yaitu mengelola Produk, mengelola Profil Usaha, mengelola Aset, mengelola Profil Pelatihan, mengelola Transaksi Penjualan COD, mengelola Riwayat Penjualan dan Pemasaran Produk Anggota, dan mengelola Biodata. Fokus utama pada anggota klaster adalah melakukan transaksi penjualan produknya guna meningkatkan status badan usaha anggota tersebut. Dalam sistem ini, anggota dapat melakukan pendaftaran Produk Anggota yang di dalamnya berisi total penjualan untuk produk tersebut, jumlah hit produk oleh (calon) pembeli (aktor Guest), dan info Like Facebook yang disertai e-mail untuk produk tersebut, sehingga dapat mengetahui produk mana yang paling banyak menarik perhatian (calon) pembeli. E-mail atau alamat Facebook yang melakukan "Like" juga dapat digunakan untuk menginformasikan produk-produk terbaru kepada para (calon) pembeli. Anggota klaster juga dapat melihat riwayat penjualan per produk dan dapat melihat informasi mengenai pembelinya, serta mampu mencetak riwayat penjualan produk. Sistem informasi klaster ini menyediakan fitur tambahan yang dapat dimanfaatkan oleh (calon) pembeli, dalam memudahkan pencarian alamat penjual dengan menggunakan teknologi Global Positioning System (GPS).

Aktor Admin Portal merupakan pengelola Sistem Informasi Desa Wisata Kandri, yang dalam hal ini adalah Universitas atau Perguruan Tinggi. Hubungan interaksi antara Admin Portal dengan sistem seperti pada gambar 7 .

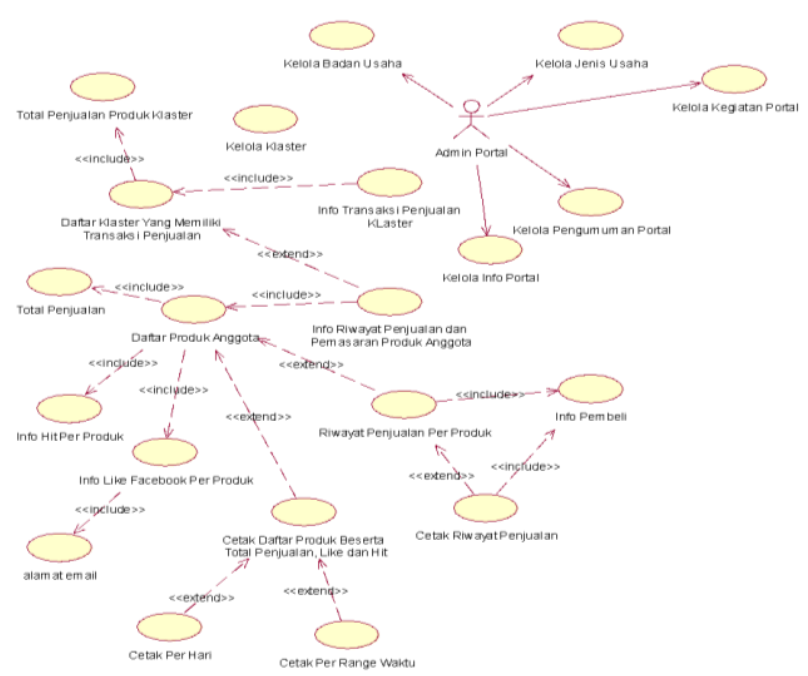

Gambar 7.Use Case Diagram Sistem Informasi Desa Wisata Kandri Aktor Admin Portal

Gambar 7 menjelaskan bagaimana hubungan antara aktor Admin Portal dengan sistem dimana Admin Portal dapat melakukan pengelolaan Klaster, pengelolaan Badan Usaha, pengelolaan Jenis Usaha, pengelolaan Kegiatan Portal, pengelolaan Pengumuman Portal, pengelolaan Info Portal, dan pengelolaan Transaksi Penjualan Klaster. Melalui menu Info Transaksi Penjualan Klaster, Admin Klaster dapat mengelola Daftar Klaster yang memiliki transaksi penjualan yang berisi total penjualan produk klaster. Menu Daftar Klaster terhubung dengan menu Riwayat Penjualan dan Pemasaran Produk Anggota yang berisi Daftar Anggota yang terhubung ke menu Riwayat Penjualan per Produk.

\section{IMPLEMENTASI}

berbasis web, diimplementasikan menggunakan bahasa pemrograman PHP dan basis data MySql. Untuk mempermudah dalam perawatan aplikasi, maka sistem dibangun menggunakan framework codeIgniter dan arsitektur Model View Controller (MVC). Untuk dapat menampilkan peta lokasi produk usaha anggota klaster, aplikasi memanfaatkan GoogleMap API sebagai server map. Guna meringankan beban kapasitas memori, maka implementasi penyimpanan dan kelola visualisasi data video, menggunakan fasilitas dari YouTube. Implementasi aplikasi Sistem Informasi Desa Wisata Kandri tersebut, untuk POKDARWIS Pandanaran dapat dilihat pada 
gambar 8, sedangkan untuk POKDARWIS Suko Makmur dapat dilihat pada gambar 9.

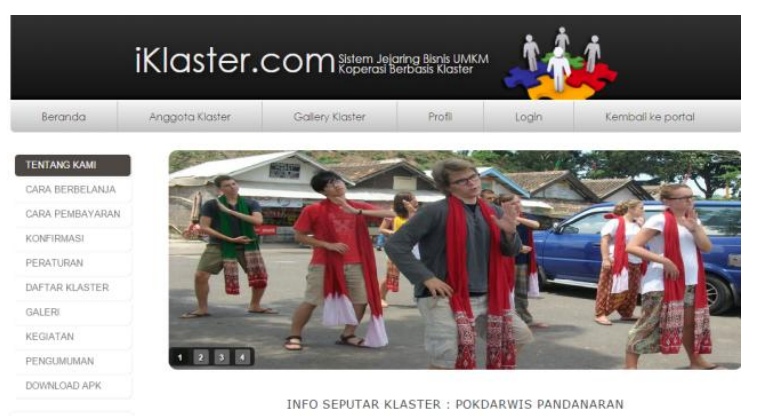

Gambar 8. Halaman Beranda POKDARWIS Pandanaran

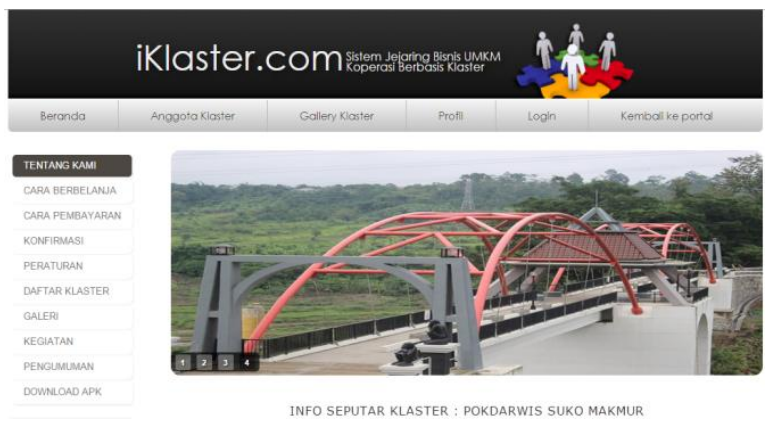

Gambar 9. Halaman Beranda POKDARWIS Suko Makmur

Sistem Informasi Desa Wisata Kandri, pada prinsipnya merupakan pengembangan dari teknologi tepat guna yang sudah berjalan yaitu Sistem Jejaring Bisnis UMKM Koperasi berbasis Klaster, dengan domain iKlaster.com, memiliki pengembangan bagi klaster pariwisata di desa Kandri adalah sebagai berikut:

1) Fasilitas galeri foto dan video, yang dipergunakan untuk menyajikan informasi kelompok klaster pariwisata di desa wisata yang lebih representatif, format data lebih variatif, yaitu dapat disajikan kedalam format teks, gambar dan video, sehingga lebih menarik. Gambar 10 merupakan tampilan galeri video milik klaster, yang dapat diakses oleh publik atau aktor Guest. Gambar 11 merupakan tampilan halaman kelola video yang hanya dapat diakses oleh aktor Admin Klaster.

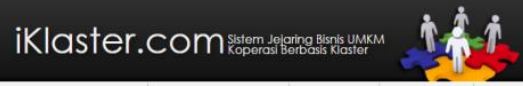
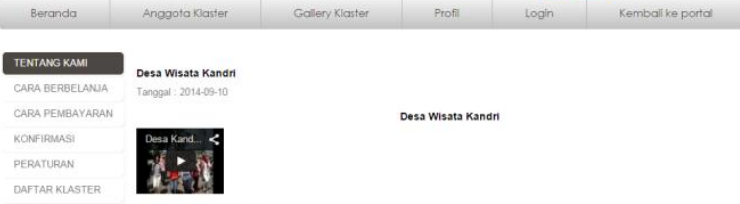

Gambar 10. Halaman Galeri Video Klaster

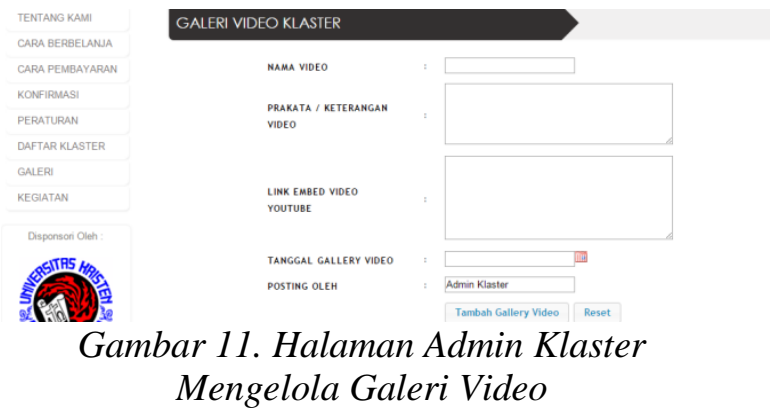

2) Fasilitas stratifikasi klaster yang merupakan informasi pengelompokan tahapan pertumbuhan klaster, yaitu Klaster Pemula, Klaster Berkembang dan Klaster Maju. Pada tahap ini, stratifikasi klaster yang dapat diakses adalah pengembangan yang telah dilaksanakan anggota klaster, pengembangan yang telah diusulkan anggota klaster, potensi klaster, aset anggota klaster, dan laporan klasifikasi klaster berdasarkan total penjualan dan aset anggota. Fasilitas ini hanya dapat diakses oleh Admin Klaster. Gambar 12 dan gambar 13 menunjukkan halaman kelola pengembangan anggota klaster.

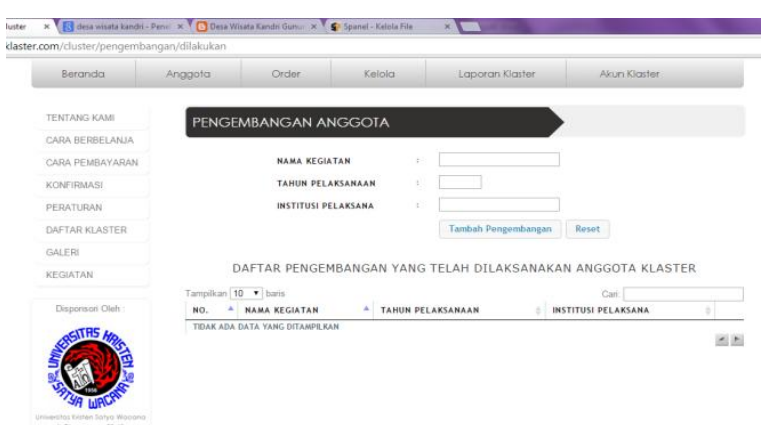

Gambar 12. Halaman Admin Klaster Mengelola Pengembangan yang Telah Dilaksanakan Anggota Klaster 


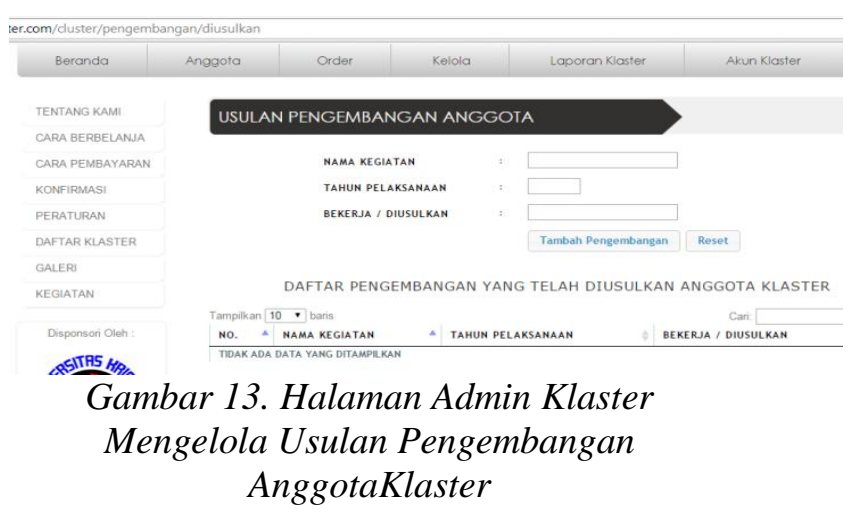

Admin Klaster juga diberikan fasilitas untuk mengelola informasi terkait potensi yang dimiliki, yang belum tergarap dan usulan pengelolaan potensi tersebut. Tampilan pengelolaan potensi klaster dapat dilihat pada gambar 14. Selain potensi, klaster juga dapat mengelola informasi terkait aset para anggotanya yang dapat dilihat pada gambar 15. Data aset anggota klaster berupa nama aset dan nominal dalam nilai rupiah. Untuk kebutuhan stratifikasi klaster, data yang dapat dikelola klaster yaitu data laporan pelatihan yang telah dilaksanakan oleh anggota maupun pengurus klaster. Data pelatihan ini dapat dilihat pada gambar 16 .

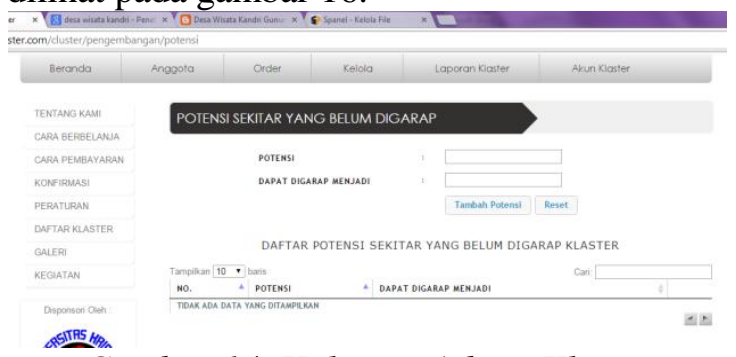

Gambar 14. Halaman Admin Klaster

Mengelola Potensi Sekitar yang Belum Digarap Klaster

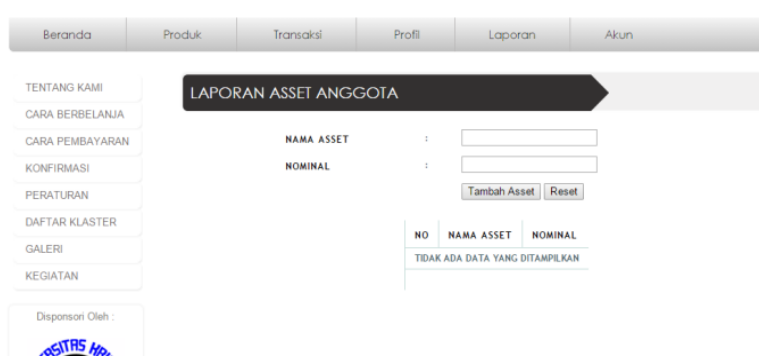

Gambar 15. Halaman Anggota Klaster Mengelola Aset

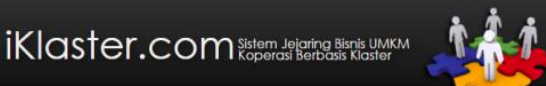

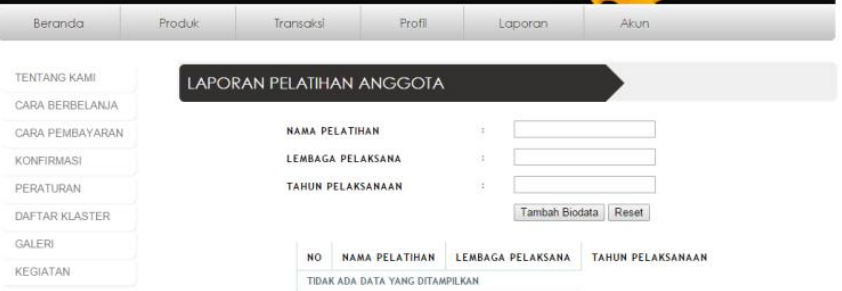

Gambar 16. Halaman Anggota Klaster Mengelola Informasi Pelatihan Anggota

3) Fasilitas kelola transaksi penjualan produk anggota klaster. Fasilitas ini diberikan bagi anggota klaster untuk mendapatkan informasi transaksi penjualan produk yang dimilikinya, baik transaksi penjualan secara online pada aplikasi maupun penjualan tidak secara online atau COD (cash on delivery). Data transaksi penjualan ini sangat penting bagi klaster karena dipergunakan sebagai salah satu parameter stratifikasi klaster untuk klasifikasi usaha klaster.

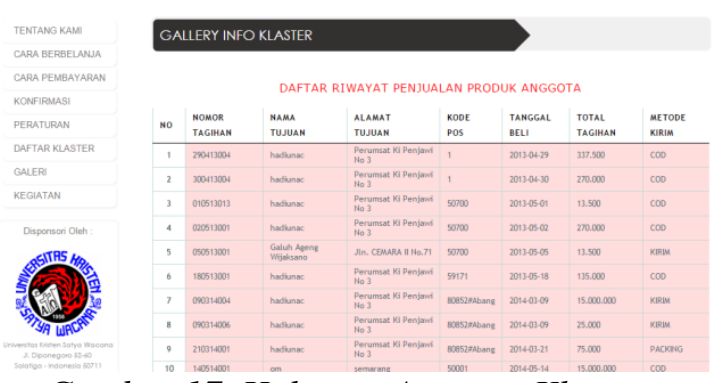

Gambar 17. Halaman Anggota Klaster

Laporan Riwayat Transaksi Penjualan Online

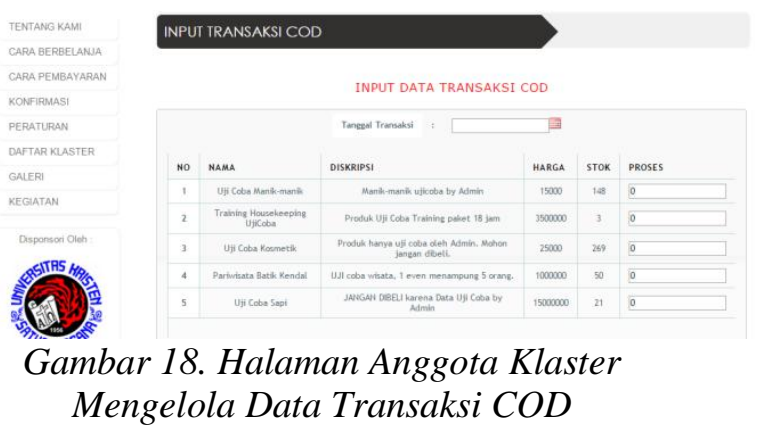

4) Fasilitas pemantauan klasifikasi usaha klaster. Fasilitas pemantauan klasifikasi usaha klaster merupakan laporan stratifikasi klaster, dimana pada tahap ini masih berdasarkan pengolahan data total aset anggota klaster dan total penjualan produk anggota klaster. Klasifikasi usaha 
klaster terbagi kedalam kelompok usaha mikro, kecil dan menengah.

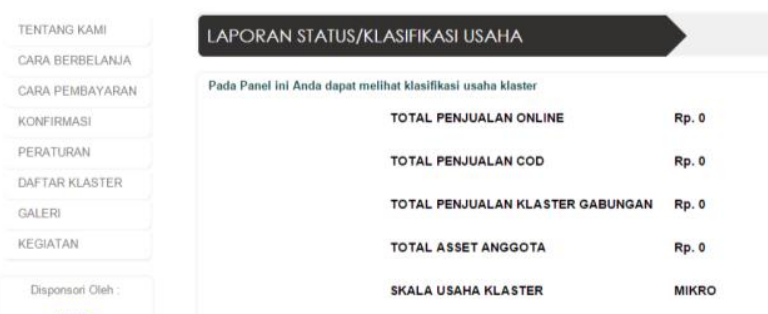

Gambar 19. Halaman Admin Klaster Laporan Klasifikasi Usaha Klaster

5) Fasilitas pemantauan promosi produk. Fasilitas pemantauan promosi produk dipergunakan oleh anggota klaster untuk mengetahui tingkat keberhasilan promosi melalui aplikasi sistem jejaring usaha UMKM berbasis klaster iKlaster.com. Data diperoleh dengan cara aplikasi mencatat jumlah Share dan Like pada produk anggota klaster oleh pihak lain melalui media sosial, yaitu Facebook, serta jumlah hit halaman produk.

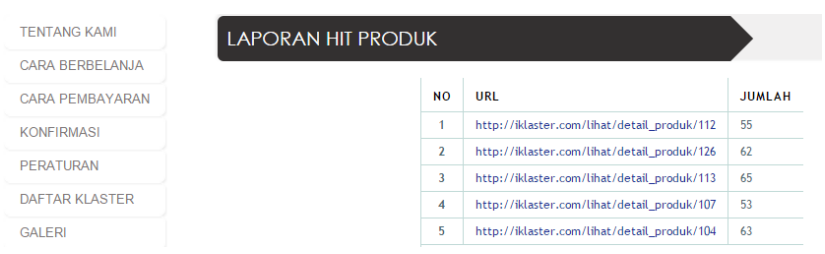

Gambar 20. Halaman Anggota Klaster Laporan Hit Produk

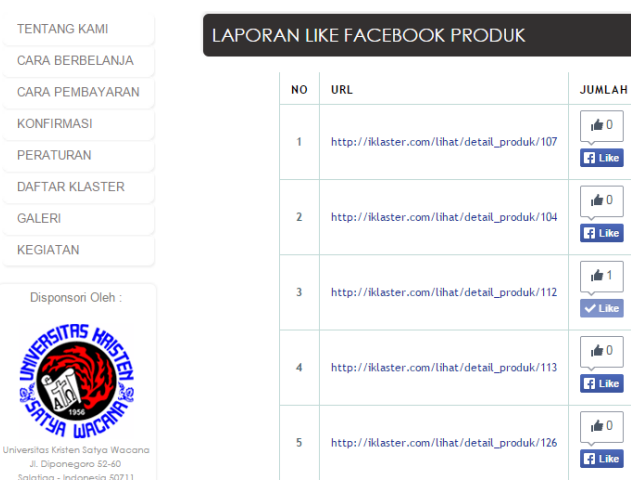

Gambar 21. Halaman Anggota Klaster Laporan Like Produk

Laporan data jumlah Hit produk seperti gambar 20, dapat diperoleh apabila ada orang atau aktor Guest pada aplikasi telah membuka halaman produk yang terdapat pada halaman yang tertera pada alamat url produk. Sedangkan, laporan data jumlah Like atau Share ke aplikasi media sosial Facebook seperti gambar 21, dapat diperoleh apabila ada aktor Guest yang memiliki account facebook melakukan klik Like pada button yang tersedia pada halaman detil produk seperti terlihat pada gambar 22.

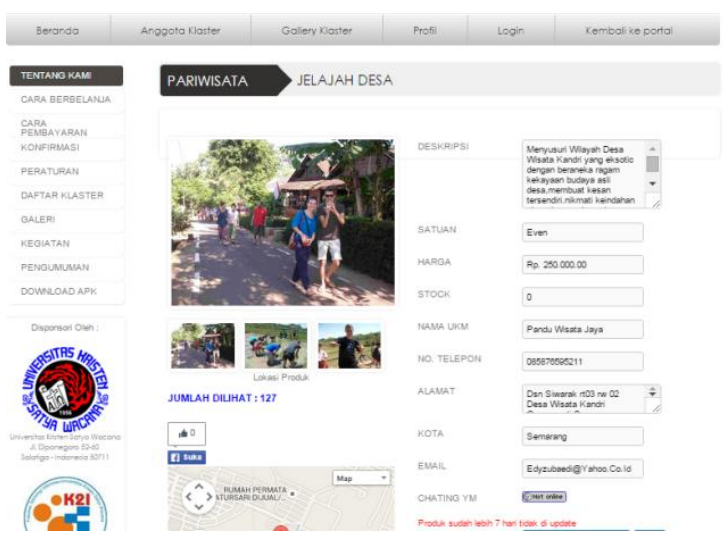

Gambar 22. Halaman Detil Produk Anggota Klaster

\section{KESIMPULAN}

Kesimpulan yang dapat diambil dari pelaksanaan Program Penerapan dan Pengembangan Teknologi Tepat Guna, dengan judul Perancangan dan Implementasi Sistem Informasi Desa Wisata Kandri Berbasis Web adalah sebagai berikut: (1) Sistem informasi telah dirancang untuk dapat dipergunakan oleh kelompok klaster usaha sebagai aplikasi $e$ commerce, yang memiliki fitur social plugins sebagai sarana pemasaran produk. (2) Sistem informasi juga dapat dipergunakan oleh klaster usaha, yaitu klaster pariwisata atau POKDARWIS sebagai pusat data dan informasi kelompok, antara lain data profil kelompok dan anggota, data pengumuman dan informasi kegiatan kelompok, dan deskripsi usaha anggota. (3) Sistem informasi dapat dipergunakan sebagai sarana pemantauan pengembangan stratifikasi dan klasifikasi klaster usaha. Sedangkan rekomendasi pengembangan hasil penerapan teknologi tepat guna ini antara lain: (1) Komponen data sebagai material stratifikasi klaster, dapat dikembangkan sesuai kebutuhan stakeholder seperti pemerintah daerah dan investor, supaya dapat dipergunakan untuk pengembangan kualitas kelompok klaster yang pada hakekatnya merupakan pelaku usaha UMKM. (2) Dikembangkan sebuah aplikasi service guna integrasi data dan informasi antara kelompok klaster usaha dengan pemerintah daerah (baik kota /kabupaten maupun provinsi) dan lembaga Perguruan Tinggi, 
sehinga dinas pemerintah yang terkait dan pihak Perguruan Tingi, dapat memperoleh data yang tepat dalam upaya peningkatan kualitas pembinaan klaster usaha dan UMKM.

\section{DAFTAR PUSTAKA}

1. Hidayat, Z. N., dkk.. 2010. Perancangan dan Implementasi Sistem ECommerce dengan Menggunakan CMS OpenCart dalam Upaya Meningkatkan Penjualan dan Pemasaran (Studi Kasus: UD. La Tanza Kecamatan Dau Malang). http://jrmsi.studentjournal.ub.ac.id/index.p hp/jrmsi/article/view/76. Diakses pada tanggal 28 Oktober 2015.

2. Setyawan, Sholeh Hadi. 2013. Perancangan Aplikasi Web E-Business untuk Klaster Industri Alas Kaki di Jawa Timur. Jurnal Teknik Elektro dan Komputer Vol. I, No. I, April 2013, 74-83.

3. Aprillia, N. S., dkk.. 2013. Aplikasi Web pada Desa Wisata Sambi Yogyakarta Sebagai Media Promosi. Yogyakarta: STMIK AMIKOM.

4. BPMD Jateng. 2012. Stratifikasi Klaster Di Jawa Tengah.Semarang: Badan Penanaman Modal Daerah Provinsi Jawa Tengah. 